\title{
Employee Engagement Practices in Organized Retail Sector: an Empirical Study with Respect to Ernakulam Town
}

\author{
Sabu K. Nair ${ }^{1 *}$, B. Chandrachoodan Nair ${ }^{2}$ \\ ${ }^{I}$ Research Scholar, Faculty of Management Studies, Noorul Islam Centre for Higher Education, Thucklay, Tamil Nadu, India. \\ ${ }^{2}$ Principal \& Director, Institute of Technology Mayyil, Kannur, Kerala, India. \\ *Corresponding author E-mail:sabudaffodils@gmail.com
}

\begin{abstract}
Dynamic Employee Engagement envelops and interfaces a huge scope of administration teach which swings it to be a far reaching idea. Employee Engagement is an approach in the workplace resulting in the accurate environment for all the employees working in an organisation to voluntarily give of their best each day with the commitment towards organization's goals and values. This paper tries to find practices of Employee Engagement prevailing within the organized retail industry in Ernakulum district. The Study has been carried out in various organised retail stores like Future - Bigbazar, Aditya Birla - More, Reliance Trends, Reliance Fresh, Reliance Foot Print \& among the E retailers like Daily Fish \& Fresh to Home .The survey was conducted among 50 employees from the mentioned companies in Ernakulum district. The objective of the paper is to study the Employee Engagement Practices which the organised retail Industry follows in Ernakulum district. The study examines the importance of job clarity, fun at work, work conditions, rewards \&recognition, empowerment, co-worker support, commitment, passion and work Relationship. The findings of the study shows that rewards and recognition and work conditions plays a major role in employee engagement among organised retail companies which leads to increased productivity, retention, commitment and profitability.
\end{abstract}

Keywords: Employee engagement, organized retail, rewards\& recognition, work condition, work relationship.

\section{Introduction}

The retail industry in India has emerged as one of the most vibrant and fast growing industry. In global retail industry ranking, India holds 5thposition. The retail industry in India accounts over $10 \%$ of Gross Domestic Product (GDP) and contributes 8 percent of employment. The Industry has got immense potential because of the increase in private and foreign participation, rise in per capita income, life style changes in middle class segment and digital connectivity. The rising population and due to urbanisation in the country, added the count of Tier (2) and Tier (3) cities. In last one decade the count of super markets has witnessed a growth from 500 to 8500 numbers. India's retail market is expected to cross US $\$ 1.1$ trillion revenue with a growth of $60 \%$ by the year 2020 .

Sorted out retailing is the way toward offering products or stock all under one rooftop in a settled area, for example, a departmental store, hypermarket, general store or even a comfort store as appeared in Figure 1.Composed retail additionally incorporates web retailing, which is the way toward purchasing and offering items and administrations, for example, money down, card on conveyance, or preliminary administrations, through the web. In India, Organized retail holds $9 \%$ of piece of the pie in total retail space with a valuation of $\$ 60$ billion whereas balance 91 percentage of market is constituted by unorganized retail market. The organized retail market in India is growing at a Compound Annual Growth Rate (CAGR) of 24.26 percent in terms of revenue over the period 2013-2018. While the general retail advertise is required to develop at 12 for each penny for each annum, sorted out retail would grow twice as quick at 20 for each penny for each annum and customary exchange at 10 for each penny.

The sorted out section regularly contains more prominent consistence of tax collection and better work law checking framework. Retailing is never again just stocking and offering yet it is about effective administration of production network, creating wholesaler and seller relationship, client encounter, imaginative marketing, convenient unwaveringness drives and limited time battles.

In retail area, representatives assume an indispensable part in expanding the deals and client encounter. Retail associations require drew in representatives to develop and succeed and positively affect the client encounter. In the present aggressive situation, the representative commitment in the composed retail part is an inexorably crucial necessity to keep up praiseworthy client benefit levels and furthermore to boost association profitability regarding deals and administration.

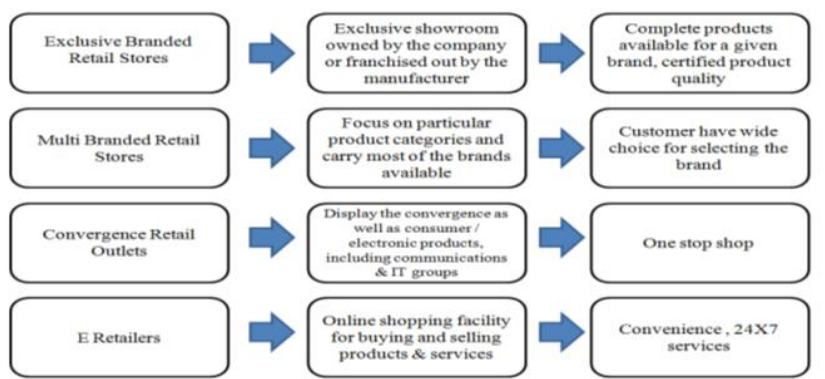

Figure 1: Organized Retail Formats in India 


\section{Literature Review}

Representative commitment is how much people are actually dedicated to helping an association by completing a superior employment than what is required to hold the activity. As per Tim Copyright (C) 2018 Authors. This is an open access article dispersed under the Creative Commons Attribution License, which grants unlimited utilize, dissemination, and proliferation in any medium, gave the first work is legitimately referred to.

Rutledge, really connected with representatives are pulled in to, and enlivened by, their work ("I need to do this"), submitted ("I am committed to the achievement of what I am doing"), and intrigued ("I adore what I am doing") (Seijts and Crim, 2006).

Worker Engagement is the positive inclination that representatives have towards their occupations Employee Engagement Practices in Organized Retail Outlets (An Empirical 699 and furthermore the inspiration and exertion they put into it (Macey and Schneider, 2008).

Kahn (1990) characterizes worker commitment as the bridling of association individuals' selves to their work parts; in commitment, individuals utilize and convey what needs be physically, psychologically, and sincerely amid part exhibitions.. Yet other researchers have claimed that employee engagement depends on the levels of empowerment in a job and that jobs should fit employees' interests (Lloyd 2004, \& MacDonald 2002).Personal relationships have also been found to impact employee engagement. Recent research has established that family stress and work related stress may be interlinked (Moore, 2004, Crabtree, 2005). Siddhanta, et al (2010) has studied employee engagement in multiple sectors in India and they have found that engagement depends on four major conditions in the workplace: Organization's culture, continuous reinforcement of people focused policies, meaningful matrices and organizational Performance. Corporate culture helps an organization to connect with the employees, gives them empowerment in decision making process and develops them to shoulder greater responsibilities. Their study has revealed that continuous reinforcement happens when an organization frames policies which act as facilitator towards accomplishment of goals by the employees and there by the organization itself. Organizational performance leads to pride, job satisfaction, trust and a sense of belongingness to the organization.

\section{Problem Statement}

Similar study has not been undertaken to comprehend the employment engagement practices in organised retail sector with reference to Ernakulam town.

\section{Objective of the Study}

1. To study the employee engagement practices in organized retail sector.

2. To measure the importance of rewards \& recognition in employee engagement.

\section{Methodology}

To satisfy the destinations of the investigation, essential information is gathered from fifty representatives working with sorted out retail in Ernakulum region by managing the organized poll. The workers are chosen by receiving the Multistage and Simple irregular testing procedure. The respondents constitutes working representatives of different retail locations like
Huge Bazar, More, Reliance Trends, Reliance Fresh, Reliance Foot Prints and from E-retailers, for example, Daily fish and Fresh to Home.

The working conditions, work clearness, duty, associates support, prizes and acknowledgment related inquiries are incorporated into the poll by receiving Likert 3 point scale

\section{(3-High, 2-Medium and 1 Low).}

The optional information is gathered from different refereed diaries, Magazines, Internet and pertinent records of chosen organizations. Factual devices utilized are

unmistakable examination, one example t-test.

Analysis \& interpretations

The below Table 1 shows descriptive statistics regarding factors influencing employee engagement, in this the factors influencing employee engagement like job clarity, fun at work, work conditions, reward and recognition, empowerment, co-workers support, commitment, passion and work relationship and mean, standard deviation, standard error mean are shown.

Table 1: Mean and Standard Deviation of Factors influencing Employee Engagement

\begin{tabular}{|c|c|c|c|c|}
\hline & N & Mean & Std. Deviation & $\begin{array}{c}\text { Std. Error } \\
\text { Mean }\end{array}$ \\
\hline Job Clarity & 50 & 2.0000 & 0.8081 & 0.1143 \\
\hline Fun at Work & 50 & 1.6400 & 0.4849 & 0.0686 \\
\hline Working Conditions & 50 & 2.6600 & 0.4785 & 0.0677 \\
\hline Rewards \& Recognition & 50 & 2.3200 & 0.9570 & 0.1353 \\
\hline Empowerment & 50 & 2.0000 & 0.8081 & 0.1143 \\
\hline Co Workers Support & 50 & 1.6800 & 0.9570 & 0.1353 \\
\hline Commitment & 50 & 2.0000 & $.00000 \mathrm{a}$ & 0.0000 \\
\hline Passion & 50 & 2.0000 & 0.8330 & 0.1178 \\
\hline Work Relationship & 50 & 2.3200 & 0.9355 & 0.1323 \\
\hline
\end{tabular}

Out of various facilities provided in the organisation, working condition is more significant. Good working condition Instigate and encourage people to work more .The above Table 1 shows majority of respondents feels as working condition is the most influencing factor (mean score 2.66) followed by rewards and recognition (mean score 2.32) while fun at work is the least influencing factor (mean score 1.64). The following Table 2 shows the result of one sample $t$ test in which the significance level of each factors influencing employee engagement in retail stores.

Table 2: One sample t test of factors influencing employee engagement

\begin{tabular}{|c|c|c|c|c|}
\hline Items & Mean & t & df - & Sig. (2- Tailed) \\
\hline Job Clarity & 2.0000 & 0.000 & 49 & 1.000 \\
\hline Commitment & 1.6400 & -5.250 & 49 & 0.000 \\
\hline Working Conditions & 2.6600 & 9.753 & 49 & 0.000 \\
\hline Rewards \& Recognition & 2.3200 & 2.364 & 49 & 0.022 \\
\hline Empowerment & 2.0000 & 0.000 & 49 & 1.000 \\
\hline Co Workers Support & 1.6800 & -2.364 & 49 & 0.022 \\
\hline Fun at Work & 2.0000 & 0.000 & 49 & 1.000 \\
\hline Passion & 2.0000 & 2.419 & 49 & 1.000 \\
\hline Work Relationship & 2.3200 & 0.000 & 49 & 0.019 \\
\hline
\end{tabular}

Test Value $=2$

The Table 2 shows the result of $\mathrm{t}$ test details collected from respondents regarding the factors influencing employee engagement, Since 3 point scale is used test value is set as 2 . Based on the analysis, we infer that when we consider $5 \%$ significance level working conditions, reward and Recognition possess a mean score above 2 whereas commitment co-worker support has a mean score of 2 and factors like job clarity, empowerment, fun at work, work relationship has got a mean score below 2 (i.e., below average) therefore it can be considered that working conditions, reward and recognition plays a major role in employee engagement for retail organisations.[10 and 11] 


\section{Conclusion}

Through the study it can be concluded that engaged employees lead to increased productivity, retention, commitment and profitability. Majority of the employees are of the view that working conditions followed by rewards and recognition, work relationship are the few important factors that influence employee engagements, therefore retail organisations should recognise employees as powerful contributors to the company's profit. In the present scenario raising and maintaining employee engagement practices lies in the hand of an organisation. Hence, it is inevitable need for retail organizations to inculcate employee engagement practices in the growing organized retail sector.

\section{References}

[1] Seijts GH \& Crim D, "What Engages Employees the Most or, the Ten C's of Employee Engagement", Ivey Business Journal, (2006).

[2] Macey WH \& Schneider B, "The Meaning of Employee Engagement", Industrial and Organizational Psychology, Vol.1, No.1, (2008).

[3] Kahn WA, "Psychological Conditions of Personal Engagement and Disengagement at Work", Academy of Management Journal, Vol.33, No.4, (1990), pp.692-794.

[4] Lloyd J, "Offer Empowerment to Encourage Engagement", Triangle Business Journal, Vol.15, No.1, (2004).

[5] Mac Donald M, "How Companies can Find Renewed Focus during Uncertain Times", Journal of Communication Management, Vol.6, No.3, (2002), pp.220-227.

[6] Moore K, "The Healthy Balance among Work, Family, and Personal Relationships: Factor Fiction?", $4^{\text {th }}$ Annual Conference on Proceedings of the APS Psychology of Relationships Interest Group, (2004), pp.79-84.

[7] Crabtree S, "Engagement Keeps the Doctor Away; A happy Employee is a Healthy Employee", According to a GMJ Survey, Gallup Management Journal, (2005).

[8] Siddhanta A \&Roy D, "Employee Engagement: Engaging the $21^{\text {st }}$ Century Workforce", Asian Journal of Management Research, Vol.1, No.1, (2010)

[9] India Retail Summary (February 2018), Retrieved from www.ibef.org/industry/retail-India

[10] Akhpanov, S. Sabitov, R. Shaykhadenov (2018). Criminal pre-trial proceedings in the Republic of Kazakhstan: Trend of the institutional transformations. Opción, Año 33. 107-125.

[11] Z Yesembayeva (2018). Features of the legal status of judges: Kazakhstan experience and foreign realities Opción, Año 33. 447 474 